Journal of Development and Communication Studies, Vol. 8. No. 1, January -June, 2021 ISSN (Online \& Print): 2305-7432. http://www.devcomsjournalmw.org

\title{
Impact of Resource Distribution and Availability on Primary Schools Pupil Learning Outcomes: Case Study of Chintheche Education Zone, Nkhata Bay, Malawi
}

Mercy Khumbo Nyirenda, Zolozolo Community Day Secondary School, Mzuzu, Malawi. Email: mercymanda1978@gmail.com

\begin{abstract}
This study investigated the impact of resource distribution on learning outcomes on nine purposively selected primary schools in the Chintheche Education Zone (previously known as Chihame Zone 1), Nkhata Bay District. Criteria for eligibility were that a school should have administered primary school leaving examinations at least three (3) times and was easy to access by public transport. In addition to document analysis, the study collected data using a questionnaire administered to the head teachers of each school, the Primary Education Advisor (PEA), and District Education Manager (DEM). Descriptive statistical analysis was done to compare pupil performance between schools with optimal resource availability and those without. The study found that the distribution of resources in the Chintheche Education Zone is unequal even though the zone is under one Primary Education Advisor. Schools closest to the trading centre have more resources and perform better than schools located far away from the trading centre and lacking almost in everything. The findings suggest that the unequal distribution of resources affects selection of pupils to secondary schools. The study recommends that fair and equitable distribution of resources would go a long way to achieving equity in access to secondary education.
\end{abstract}

Keywords: Primary education, resources, school selection, equitable access, Malawi

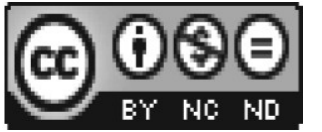

(C) 2020. The author. This work is licensed under the Creative Commons Attribution 4.0 International License (CC-By-NC-ND). Users may freely share and redistribute this work provided that the author and the Journal of Development and Communication Studies are fully acknowledged. Users may not tweak or remix 
and offer this work for sale. The full license may be accessed at

https://creativecommons.org/licenses/by-nc-nd/4.0/

To cite this article: Nyirenda, M.K., (2021). Impact of Resource Distribution and Availability on Primary Schools Pupil Learning Outcomes: Case Study of Chintheche Education Zone, Nkhata Bay, Malawi. Journal of Development and Communication Studies, 8(1) 239 - 260

https://dx.doi.org/10.4314/jdcs.v8i1.12

\section{Introduction}

Education is important for socio-economic development and industrial growth. It mentally prepares learners to effectively contribute to promotion and sustainability of the country's social economic development (Ngulube 2010:14). Evidence from Africa shows that an increase in learners attaining basic education increases the rate of economic growth, improves agricultural productivity, increases the employability of the labour force, reduces infant and maternal mortality, and helps to slow down population growth (UNICEF1993:135). According to the Government of Malawi (GoM) (2012:29), education is an instrument for empowering the poor, the weak and the voiceless as it provides them with equal opportunity to participate in local and national development and enables the individuals to deal effectively with the demands and challenges of everyday life. The Malawi Growth and Development Strategy II (GoM, 2012: 38) intended to ensure that education was accessible to all school going children. Milner et al (2001: 52) point out that in order to achieve this, equitable resource distribution in the form of infrastructure, services, learning materials, and teachers are essential to afford all primary school learners equal opportunities to learn. For this purpose, the Government of Malawi introduced free primary education (FPE) in 1994 to attain the education for all goals. The policy led to increased enrolment from 1,895,423 in 1993 to 2,860,819 in 1994 and 3,671,481 by 2009.While the policy created education opportunities for primary school going children, the quality was seriously compromised (UNESCO 1998:48). Among reasons for low quality was inadequate resource availability.

The Government of Malawi has carried out a number of initiatives aimed at improving quality and relevance of education as well as addressing issues of inequitable resource distribution. For example, teacher training expanded due to the introduction of Open Distance Learning (ODL) in all public Teacher Training Colleges (GoM 2012: 30) to complement traditional teacher training. Other efforts have included the introduction of complementary basic education programme, life skills 
education, and increased provision of teaching and learning materials (MOEST 2008:12).

With regard to infrastructure developments in primary schools, several attempts have been made to construct classrooms, toilets, and provide potable water through the Local Development Fund (LDF) and projects funded by donors such as the World Bank under the International Development Agency (IDA), the African Development Bank (AFDB), UNICEF, the Canadian International Development Agency (CIDA), and the British Department for International Development (DfID), the US Agency for International Development (USAID), the German International Cooperation Agency (GiZ), Danish International Development Agency (DANIDA), and Build On. These projects are often facilitated by NGOs such as Action Aid Malawi, WVI, Plan Malawi and Concern Universal which have been very instrumental in the construction of school infrastructure particularly in rural areas (Ng'ambi 2010).

Ng'ambi (2010) points out that the donor support in the education sector is geared to improving quality and access to Free Primary Education (FPE) through rehabilitation or construction of schools; providing learning, and teaching materials and sanitation services. These factors suggest that quality education is a combination of different factors such as qualified teachers, availability of relevant teaching and learning materials as well as school infrastructure like construction of classrooms, toilet facilities and provision safe water supply, among many others. This is why the effective and equitable of distribution of these resources must be very essential in the achievement of quality education in Malawi generally and in Chintheche Education Zone in particular.

UNICEF (2007:26) indicates that the right to education does not only entail granting access to education but also the quality of education and the learning environment which are equally critical because education is a fundamental right for every child. Primary education is the initial and widest segment of formal learning which forms the bedrock for subsequent learning.

The majority of Sub Saharan Africa (SSA) countries adopted the Global Education for All (EFA) also called Universal Primary Education (UPE) policy in the 1990s with the aim of getting all eligible school going children enrolled in primary education by 2015. To operationalise this policy, some countries introduced free primary education. Malawi started free primary education in 1991(UNESCO 2009:20). In countries where Universal Primary Education (UPE) was instituted and direct costs of schooling eliminated, the policy created an instantaneous large increase in school 
enrolment. For example, enrolment is estimated to have increased by nearly $58 \%$ in Uganda, 75\% in Lesotho, and 22\% in Kenya (Grogan 2008:184).

The rapid increase in enrolment in primary education created a high demand for more resources (UNESCO 2009: 13). For instance, when Kenya adopted the Global Education for all policy, primary education in 2003 faced problems of increased demand for resources such as teachers, classrooms, and teaching and learning materials. According to Mathooko (2006:152), free and compulsory primary education for Kenyan children led to a rapid increase in school enrollment, in some cases by $100 \%$. The increased enrolment also raised some challenges such as some teachers resisting to take posts in rural schools. The posting to rural schools was perceived by these teachers as a form of punishment for some unknown offence. As such, rural schools were perceived by teachers and other stakeholders as dumping grounds for bad teachers (Mathooko 2006:152), forgetting that rural areas needed equally good teachers, only that teachers, especially ladies, consider rural areas as backward places with no opportunities for career growth and no social services.

Similarly, when Uganda introduced free primary education in 1997, the country also experienced shortage of teachers, classrooms, teaching and learning materials because of the rapid increase of enrollment (MOESU, 2005). According to Grogan (2008), this increase resulted in classrooms overcrowding and temporary shelters being erected because the policy implementation started before infrastructural improvements in the schools had been carried out. In addition, the increased enrolment resulted in a substantial decrease in resources available per pupil and a large increase in pupil to teacher ratio. To address this, the Uganda Government approved an Education Sector Investments Plan (ESIP) in 1998. Grogan (2008) reports that apart from further large-scale infrastructure investments, the government of Uganda committed itself to training large numbers of new teachers under the Primary Education and Teacher Development Program (PETDP). The implementation of PETDP in Uganda resulted in the achievement of a teacher-pupil ratio of 1:55; desk to pupil ratio of 1:2, and textbook-pupil ratio of 1:1 (Grogan 2008).

In Tanzania, on the other hand, the major aim of introducing Universal Primary Education was to provide children with a concrete and reliable basis for selfreliance (Chongo 1994:42). However, the enormous expansion of primary school enrolment under UPE affected teaching and learning because the supply of education resources, especially textbooks, was inadequate in all the subjects and in all grades (Chongo, 1994:42). Chongo (1994) stresses that the Tanzania Government appealed to parents to contribute to their pupils' education by providing learning materials such as notebooks and textbooks. This was based on the realisation that Government alone 
could not provide all the required resources. The outcome of this approach was children from relatively wealthy families had better learning materials than those from poor families (Chongo 1994:43).

An investigation by Ndabi (1985:37) in Tanzania to establish the relationship between the schools' characteristics and academic achievement in primary school concluded that learner performance in primary school leaving certificate examinations (PSLCE) tended to be better in schools with adequate learning resources. Pupils who had requisite textbooks in all the subjects performed better than pupils in schools with relatively high incidences of textbook shortages.

In Malawi Free Primary Education (FPE) increased enrolment also created high demand for classrooms, teachers, teacher's houses, teaching and learning materials such as textbooks and notebooks. UNESCO (2009:13) states that for Malawi to meet the emerging challenges, the country required about 9,000 teachers to be trained every year but only 4,000 teachers were being trained in each year. To address the problem of shortage of teachers, the Government of Malawi had to recruit unqualified teachers, a policy which ended up weakening the education system because the unqualified teachers had no teaching skills. According to Kadzamira and Chibwana (2000), in Malawi the situation was aggravated by challenges such as low number of teachers' houses, teaching and learning materials; conditions which were clearly not motivating to teachers.

In addition to general problems Malawi has faced as a result of implementing the FPE, there were serious inequalities in the distribution of resources between schools. For example, UNESCO (2009:13) reports that there were imbalances in the distribution of resources in primary schools which often resulted from inadequate investment in education. These imbalances were more observed in relation to the deployment teachers with urban schools having getting more teachers than rural schools.

An international study, the Southern and Eastern African Consortium for Monitoring Educational Quality (SACMEQ), undertaken in six countries (Namibia, Zambia, Malawi, Zanzibar, Kenya and Mauritius) found that Malawi's performance on school resources was the lowest of all six countries and was significantly worse than in Namibia and Zambia and had fallen in absolute terms over the years between 1995/96 and 2000/01 (UNESCO, 2004: 46).

Milner and Mbewe (2010) found that teacher disparities in schools were caused by various factors such as poor working conditions for teachers. For example, some primary school teachers in Lilongwe were not willing to be posted to schools that had 
no teachers' houses and poor school infrastructure in general. Teachers preferred to be posted where they could have access to social services such as banks and hospitals.

Kholowa and Mbewe (2001) and Nyondo (2013) indicated that lack of electricity was another contributing factor to the disparities in schools. Most rural areas do not have electricity, which hinders teachers from taking positions in rural areas because they would like to be using their electrical appliances such as televisions, fridges, radios and mobile phones. Not only that, lack of electricity also hinders pupils from studying at night while pupils in the urban areas and those close to townships can study even at night in their homes or in schools that have electricity.

Water and sanitation issues also impact the school learning atmosphere. According to the Malawi Government (GoM 2012: 38), improved water supply and sanitation facilities in schools significantly contribute to the quality of education by reducing disease incidences among children and staff, improving school attendance and retention, particularly among girls, attracting and retenaining teachers and providing a more conducive learning environment.

UNICEF (2009) points out that the recommended pupil to toilet ratio is one per 25 girls and one for female staff, also one toilet plus one urinal $(50 \mathrm{~cm}$ of urinal wall) per 50 boys, and one male staff. However, in Malawi schools, particularly those in rural areas, often completely lack drinking-water and have inadequate and poor sanitation facilities which situation affects the quality of learning. Girls and boys are likely to be affected in different ways and this may contribute to unequal learning opportunities. Sometimes girls are more affected than boys because the lack of sanitary facilities means that they cannot attend school during menstruation.

In order to curb the problem of distribution of resources in schools, the Government of Malawi introduced some measures such as decentralised education management so as to monitor teachers effectively. In addition, the government introduced distance learning for unqualified teachers, increased budget allocation to the education sector, encouraged programmes that strengthen the link between teachers and communities around them, and pressed for more NGOs as well as donor community involvement in the provision of teaching facilities and teacher development. However, it appears there are challenges with which the Government of Malawi is failing to cope (GoM 2012:29).

The situation at national level repeats itself at local level. For example, a study conducted by Milner et al.(2001) in Machinga and Balaka revealed that less than half of the schools in Balaka but slightly more than half in Machinga had the requisite number of classrooms. The study also revealed that serious shortages of textbooks 
existed among schools. For example, in $75 \%$ of schools in Balaka only $23 \%$ of pupils had required textbooks. This number was slightly higher in Machinga where $75 \%$ of schools had $33 \%$ of pupils with all required textbooks distributed to them by the Ministry of Education, Science and Technology, Science and Technology. The situation in Nkhata Bay was not very different as the sections that follow reveal.

According to the Nkhata Bay District (2009) Social-Economic Profile, the district had 185 primary schools. The data also show that textbook to pupil ratio stood at 1:3 in 2008 which was below the required 1:1 ratio. Further, though there was progress on pupil-classroom ratio from 94:1 to 89:1, the ratio was still higher than the recommended 60:1 and the average number of teachers was 4 per school (Nkhata Bay District Council, 2009). The performance of the district, in terms of pass rate, was declining over the years from 57.5\% to 51.1\% between 2006 and 2009 and also lower than national average of $68.5 \%$ (Nkhata Bay District Council, 2010:19). This decline and low performance were blamed on inadequacy of resources in addition to deployment of unqualified teachers, and teacher and pupil absenteeism (Nkhata Bay District Council, 2009a: 98-108). It is for this reason that the District Development Plan for 2009-2012 had proposed to build 105 teacher houses, 30 classrooms and procure 1000 desks (Nkhata Bay District Council, 2009 b). As a result of these improvements, the performance of the district in primary school leaving certificate examinations rose which supports the thesis that investing in learning resources leads to improvement in educational attainment as Ndabi (1985:37) found in Tanzania.

By the time of this study, Chintheche (Chihame I) Education Zone was among the worst performers (see Table 1) coming $12^{\text {th }}$ out of 16 Education Zones in Nkhata Bay district in 2009 (Nkhata Bay District Council, 2010:19-25) but improved to number 1 in 2018.

This study sought to investigate how the distribution and availability of resources in primary schools within the Chintheche Education Zone impacts learning outcomes. The indicators of assessment were 1) availability and number of qualified teachers, 2) availability and quantity of key subject textbooks and notebooks, 3) teacher-pupil ratio 4) classroom-pupil ratio and 5) selection to secondary school.

Table 1: PSLCE Examination Results by Education Zone, 2009

\begin{tabular}{|l|l|l|}
\hline ZONE & PASS RATE & POSITION \\
\hline Bula & 78.9 & 1 \\
\hline Usisya & 60.6 & 2 \\
\hline Tukombo & 59.0 & 3 \\
\hline Mpamba & 58.6 & 4 \\
\hline
\end{tabular}




\begin{tabular}{|l|l|l|}
\hline Kachere & 58.2 & 5 \\
\hline Mazamba & 55.0 & 6 \\
\hline Chihame II & 54.6 & 7 \\
\hline St Maria Gorreti & 52.9 & 8 \\
\hline Bandawe & 52.3 & 9 \\
\hline Chikwina & 52.1 & 10 \\
\hline Kavuzi & 50.3 & 11 \\
\hline Chintheche & 44.4 & 12 \\
\hline Chombe & 44.1 & 13 \\
\hline Ruwarwe & 40.5 & 14 \\
\hline Ching'oma & 37.5 & 15 \\
\hline Chisu & 32.4 & 16 \\
\hline
\end{tabular}

\section{Findings}

\section{School enrolment}

According to various school enrolment records, from 2009 to 2012, there were 6620 pupils in the Chintheche Zone and a total of 4969 pupils in the nine (9) schools of study representing $70.2 \%$ of the schools found in the Zone. Chihame Primary School had the highest enrolment of students taking primary school leaving certificate examinations of all the targeted schools seconded by Chintheche and Mgodi Primary Schools (See Table 10).

Schools had more girls than boys enrolled in the examination class which was a likely indication that girls were participating in education. In some schools, Standard 8 showed an increase in enrolment, which could be a result of many pupils repeating the class. An over-the-years (Standards $1-8$ ) student progression analysis reveaveled that some schools experienced decreasing enrolment due, perhaps, to poor learning environments. For instance, Chipayika primary school recorded high enrolment (over 40 in Standard one but in Standard 8 there were only 17 boys and 3 girls. In 2010, 40 boys and 42 girls enrolled yet Standard 8 had only 14 boys and 1 girl. Schools with inadequate resources, and where learners see no chance of being selected to secondary school, are not able to retain pupils while schools with adequate resources are able to retain most pupils up to Standard 8.

\section{Teacher availability}

The study found that there were 67 teachers (19 females and 33 males) in the nine schools under study and the distribution varied significantly. Most of the schools had no teachers to cover all the classes. Msawa had only 4 teachers, Chipayika had 5 while Chintheche Primary School had 14 teachers. It is worth noting that Chipayika and Msawa are the most rural and unreachable schools. The study found that out of 67 
teachers, 15 were unqualified ( 8 male and 7 females) and were still on training through the programme of Open Distance Learning (see Table 3 for the distribution of qualified and unqualified teacher pupil ratio). The study revealed that the qualified teacher to pupil ratio was very high in all schools studied, Chipayika Primary School being the highest with a qualified teacher to pupil ratio of 1:196. High teacher to pupil ratio means one teacher handles more pupils than the recommended ratio of one teacher to 60 pupils (Nkhata Bay District Council, 2010). At Chipayika, work meant for four teachers is handled by one.

Table 3: Distribution of Qualified and Unqualified Teachers in Schools and Teacher to Pupil Ratio

\begin{tabular}{|l|l|l|l|l|l|l|l|}
\hline School & $\begin{array}{l}\text { Qual } \\
\text { ified } \\
\text { teac } \\
\text { hers }\end{array}$ & $\begin{array}{l}\text { ODL } \\
\text { teache } \\
\text { rs }\end{array}$ & $\begin{array}{l}\text { No. of } \\
\text { unqualifi } \\
\text { ed } \\
\text { teachers }\end{array}$ & $\begin{array}{l}\text { Teacher } \\
\text {-pupil } \\
\text { ratio }\end{array}$ & $\begin{array}{l}\text { Qualifie } \\
\text { d teacher } \\
- \text { pupil } \\
\text { ratio }\end{array}$ & $\begin{array}{l}\text { Available } \\
\text { ratio }\end{array}$ & $\begin{array}{l}\text { Recomme } \\
\text { nded } \\
\text { Ratio }\end{array}$ \\
\hline Bungano & 3 & 4 & 1 & 0 & 8 & $1: 92$ & $1: 60$ \\
\hline Chihame & 7 & 3 & 3 & 1 & 14 & $1: 95$ & $1: 60$ \\
\hline Chikumba & 1 & 3 & 1 & 1 & 6 & $1: 105$ & $1: 60$ \\
\hline Chimbere & 1 & 4 & 0 & 1 & 6 & $1: 118$ & $1: 60$ \\
\hline Msawa & 0 & 3 & 0 & 1 & 4 & $1: 73$ & $1: 60$ \\
\hline Chipayika & 0 & 2 & 0 & 3 & 5 & $1: 196$ & $1: 60$ \\
\hline Mgodi & 4 & 6 & 0 & 0 & 10 & $1: 70$ & $1: 60$ \\
\hline Chintheche & 7 & 2 & 2 & 1 & 14 & $1: 94$ & $1: 60$ \\
\hline Msomba & 1 & 5 & 1 & 1 & 8 & $1: 70$ & $1: 60$ \\
\hline Uhoho & 2 & 3 & 1 & 0 & 6 & $1: 100$ & $1: 60$ \\
\hline Total & 19 & 33 & 7 & 8 & 67 & & \\
\hline
\end{tabular}

Source: School Records

The supplementation of ODL teachers alleviated the teacher shortage, thereby reducing the teacher to pupil ratio closer to the recommended ratio of 1:60 in some schools, such as Msomba and Mgodi. However, it was still clear that teacher to pupil ratio in the rest of the schools remained above the recommended ratio.

According to discussion with the DEM, distribution of teachers is based on three main factors: a) teacher pupil ratio, 2) number of classes per school and 3) performance of the school. In light of this it would have been expected that the intention would be to increase the number of teachers to improve performance. However, the results of the study show that these factors are not reflecting what is 
happening in the Zone. For instance, some schools such as Chipayika, Chimbere, Msawa, Chikumba and Uhoho show continuous records of poor performance and yet nothing has been done to balance the ability. In addition, it appears that most of the teachers in these schools, that continuously perform poorly, are not qualified and are still undergoing training. Yet it is unclear how the government expects these unqualified teachers to improve the situation. How does the Ministry of Education, Science and Technology expect the unqualified teachers to use the instruction manual such as Teachers' Guide without being taught how to use it? The unqualified teachers were also responsible for all classes including senior classes, that is, from Standard 1 to 8. Apart from the observed impacts on selection (learning outcome), the variation among this zone illustrates the well- known pattern that better qualified teachers do not like being sent to remote areas where school infrastructure is poor.

The study also found that Chihame, Chintheche, Mgodi, Msomba and Bungano have teachers to cover all classes from Standard 1 to Standard 8. As regards teacher pupil ratio, the study found that teacher to pupil ratio was higher than 1:60 as prescribed by the Ministry of Education, Science and Technology contributes to the negative impact on schools performance. This is because large classes are difficult to manage; hence failure to meet and satisfy the pupils' needs. In addition, even though Msawa primary school meets the recommended pupil teacher ratio, it is only because of low enrolment. The school has only 4 teachers to teach from Standards 1 to 8. Pupils from schools that were showing poor performance revealed during focus group discussions that lack of teachers was contributing to their poor performance as most of the time they do not learn because one teacher has to attend to other classes. The pupils are asked to play around the school premises while the teacher is attending to another class more especially Standard 8. This suggests inadequate teaching and learning of students in lower classes contributes to poor performance in Standard 8. As such, the poor performance of schools, such as Chipayika, in primary school leaving certificate examinations is not surprising.

\section{Availability of teaching and learning materials}

\section{Textbooks}

The study found that the numbers of textbooks in different schools varied. Much as it was certainly expected that not all textbooks in every key subject in all the classes would be found, the student: textbook ratio was very high in some schools in the zone. In some schools, the pupil to textbook ratio was as high as 1 textbook to 10 pupils or even more than that. Even worse, ome schools, such as Chipayika, Msawa, Uhoho, 
and Chimbere had no textbooks in some of the key subjects such as science, mathematics, and agriculture.

An interview with Zone PEA indicated that the Government of Malawi target is to have one textbook to two pupils per core subject. It is, therefore, worrying that most schools had high pupil to textbook ratio. The study has revealed that in schools where there was shortage of textbooks, learners were facing problems in the learning process because several learners had to share one textbook which reduced concentration among them and performance has always been poor. Pupils revealed that shortage of textbooks hinder them from studying effectively at home because they do not have reference materials. If textbooks are not available, satisfactory results from learners cannot be expected.

\section{Notebooks}

The number of notebooks supplied to pupils in schools varied. Some schools such as Bungano, Chintheche, Mgodi and Msomba supplied 9 notebooks to each student in the senior classes and had very few notebook requirements gap. Schools such as Chipayika, Chimbere, Chikumba, and Msawa had high notebook requirements gaps, Chipayika being the worst in terms of notebook requirements gap. The District Education Office revealed that the Ministry of Education, Science and Technology stopped distributing notebooks to primary schools ten years earlier (2002). Instead, it provided money direct to each school in a program known as Primary School Improvement Program (PSIP) which is based on expenditure per learner. Each school is supposed to buy notebooks from this money. Every school in Nkhata Bay District is given K170, 000 (USD 528.64) per year. In the year 2011- 2012 every primary school in Nkhata Bay District was given K370, 000.00 (USD1,150.58) 50\% of which, according to the DEM, was to be used to improve quality of education by buying exercise books. Forty percent was supposed to be used towards access and equity among schools by providing things which can attract more pupils to enroll. Ten percent was supposed to be used in governance of the schools. However, the study found that the priority differs in schools. Information from the Zone PEA indicated that some schools regardless of being given money do not buy enough notebooks to distribute to pupils due to many challenges faced by the schools.

The study found that the notebooks pupils receive are not enough in all schools. The maximum number of notebooks pupils in senior class receive was 9 per term of three months each or 27 per year. Ideally every pupil in senior classes (standards 5-8) is supposed to receive one notebook per subject and there are some subjects such as English, Mathematics and Chichewa which may require two or more 
notebooks per term because the subjects require a lot of exercises. Notebooks are very important in any effective learning environment as they are useful for teachers to monitor progress of pupils. Delivery of quality education can be affected when there is no adequate supply of notebooks. The study also revealed that the money which the Ministry of Education, Science and Technology, Science and Technology gives to schools under the Primary School Improvement Program (PSIP) is not enough and does not reflect the intended purpose of expenditure per learner. For instance as already indicated each school is supposed to be given K170, 000 and if we take this amount against, for example, current enrolment of Chintheche primary school of 959, each learner would receive K177.00 (USD 0.55) for notebooks for three months. This money is not enough to buy the total required notebooks. However, schools such as Chintheche, Mgodi, and Msomba are owned by churches. Therefore, they are likely to be assisted with additional resources by the church. This could be the reason they are able to purchase more notebooks for didtribution to their students.

\section{Desks}

The expectation in primary school is to have one desk for two pupils. The study found that the distribution of desks in the Chintheche Education Zone was not consistent with the number of pupils in schools. The whole zone had a shortage of desks. For instance, Chipayika Primary School had only 13 desks.

\section{Table 6: Distribution of Desks by School}

\begin{tabular}{|l|l|l|l|l|l|}
\hline School & $\begin{array}{l}\text { Total } \\
\text { Enrolm } \\
\text { ent }\end{array}$ & $\begin{array}{l}\text { Total } \\
\text { Desks }\end{array}$ & $\begin{array}{l}\text { Pupil } \\
\text { Desk } \\
\text { Ratio }\end{array}$ & $\begin{array}{l}\text { Recom } \\
\text { mended } \\
\text { Ratio }\end{array}$ & $\begin{array}{l}\text { Desk } \\
\text { Gap }\end{array}$ \\
\hline Chikumba & 423 & 100 & $4: 1$ & $2: 1$ & 111.5 \\
\hline Msawa & 253 & 30 & $7: 1$ & $2: 1$ & 96.5 \\
\hline Chihame & 959 & 134 & $7: 1$ & $2: 1$ & 309.5 \\
\hline Uhoho & 504 & 180 & $3: 1$ & $2: 1$ & 72 \\
\hline Mgodi & 704 & 200 & $4: 1$ & $2: 1$ & 152 \\
\hline Chipayika & 490 & 13 & $30: 1$ & $2: 1$ & 232 \\
\hline Chimbere & 593 & 132 & $4: 1$ & $2: 1$ & 164.5 \\
\hline
\end{tabular}




\begin{tabular}{|l|l|l|l|l|l|}
\hline Msomba & 425 & 149 & $3: 1$ & $2: 1$ & 15.5 \\
\hline Bungano & 648 & 204 & $3: 1$ & $2: 1$ & 120 \\
\hline Total & 4969 & 1142 & $5: 1$ & $2: 1$ & 1073.5 \\
\hline
\end{tabular}

Source: School Records

This gives pupil to a desk ratio of 30:1. Other schools with high pupil/desk ratio were Chintheche and Msawa with 7:1 (refer to table 6). Primary school desks are attached to chairs. When discussing desks the implication is that chairs are included. Lack of desks and chairs implies that many pupils sit on the floor, which may be a hygiene concern and can affect pupil concentration due to discomfort and fatigue. The head teachers reported that inadequate desks also make girl pupil uncomfortable when writing because one needs to lift legs up and use the knees as a substitute for desk. Apart from writing now and then, the girl pupil is always busy attending to herself especially when changing positions to avoid peeping boys.

\section{Distribution of infrastructure}

\section{Teachers' houses}

The study found that there were a total of 21 teachers' houses in the nine schools under study. Five of the houses were found at Mgodi primary school representing $24 \%$, Bungano and Chintheche had 4 houses each representing 19\% each, the rest Chimbere, Chipayika, Chikumba, Uhoho, Msawa had one house each representing $4 \%$ each (refer to table 7 ).

\section{Table 7: Distribution of Teachers' Houses by School}

\begin{tabular}{|l|l|l|l|}
\hline School & $\begin{array}{l}\text { No. of } \\
\text { teachers }\end{array}$ & $\begin{array}{l}\text { No. of } \\
\text { houses }\end{array}$ & $\begin{array}{l}\text { Houses gap (ideal being } \\
\text { teacher to one house }\end{array}$ \\
\hline Bungano & 8 & 4 & 4 \\
\hline Chihame & 14 & 4 & 10 \\
\hline Chikumba & 6 & 1 & 5 \\
\hline Chimbere & 6 & 1 & 5 \\
\hline Msawa & 4 & 1 & 3 \\
\hline
\end{tabular}




\begin{tabular}{|l|l|l|l|}
\hline Chipayika & 5 & 1 & 4 \\
\hline Mgodi & 10 & 5 & 5 \\
\hline Msomba & 8 & 3 & 5 \\
\hline Uhoho & 6 & 1 & 5 \\
\hline Total & 67 & 21 & 46 \\
\hline
\end{tabular}

Source: School Records

According to the Chintheche Education Zone PEA, the shortage of teachers' houses has hindered teachers taking posts in schools such as Chipayika. Even renting houses becomes difficult since the schools are far from Chintheche Township where there are available houses for rent. This is different from Bungano, Chihame, Chintheche, Msomba, and Mgodi schools which attract teachers because of availability of teachers' houses in the schools or at the nearby Chintheche Township for rent. Poor performance at the schools may, therefore, be linked to inadequate teachers, use of unqualified teachers as well as teachers being absent from duties or tired due to long travel from residences far away before teaching stations.

\section{Classrooms}

The study found that there were a total of 55 classrooms in the nine schools under study and that most of the schools in the Zone had inadequate classrooms leading to a high classroom to pupil ratio of 1:85 against required 1:60. The study also found that the Zone still required 80 more classrooms to meet the recommended ratio of 1:60.The only schools best supplied with classrooms were Mgodi and Msomba. Chihame, Chintheche, Msomba and Bungano schools had separate classrooms for each class from Standard 1 to Standard 8 but classes were very congested because of high enrolment of pupils. The rest of the schools were poorly supplied with classrooms, Chipayika and Msawa being the worst, with only 2 classrooms each for 490 and 253 total enrolments respectively (see Table 8). In all, the schools in the Chintheche Education Zone had a shortage of 29 classrooms, which is rquivalent to more three full school at one classroom per level/Standard/Grade.

Table 8: Distribution of Classrooms by School 


\begin{tabular}{|l|l|l|l|l|}
\hline School & $\begin{array}{l}\text { Total } \\
\text { enrolment }\end{array}$ & $\begin{array}{l}\text { No. of } \\
\text { classrooms }\end{array}$ & $\begin{array}{l}\text { Rooms } \\
\text { required } \\
\text { at 1: } 60\end{array}$ & $\begin{array}{l}\text { Classroom } \\
\text { Gap }\end{array}$ \\
\hline Bungano & 648 & 8 & 10 & 2 \\
\hline Chihame & 959 & 9 & 15 & 6 \\
\hline Chikumba & 423 & 4 & 7 & 3 \\
\hline Chimbere & 593 & 4 & 10 & 6 \\
\hline Msawa & 253 & 2 & 4 & 2 \\
\hline Chipayika & 490 & 2 & 8 & 6 \\
\hline Mgodi & 704 & 14 & 11 & 0 \\
\hline Msomba & 425 & 8 & 7 & 0 \\
\hline Uhoho & 504 & 4 & 8 & 4 \\
\hline Total & 4969 & 55 & 80 & 29 \\
\hline
\end{tabular}

Source: School Records

Shortage of classrooms makes delivery of education difficult because most classes are conducted in a poor environment such as under trees, temporary sheleter, and in open spaces where students are easily distracted according head teachers from these schools. The problem becomes critical during the rainy season because classes are cancelled whenever there is rain. This was also a contributing factor to the poor performance of pupils.

\section{Sanitation facilities}

The study found that there were a total of 104 toilets in the nine (9) schools of study. With an enrolment of 4969 pupils, this translates into a ratio of one toilet for 47 pupils which was above the expected national recommended averages of 1:30 (UNICEF 2009; Nkhata Bay District Council, 2010). The study revealed that there was need for 61 more toilets to be constructed in order to meet the recommended national toilet pupil ratio. The worst school was Chimbere with 1:88. The best toilet supplied school was Msomba primary school with a ratio of 1:26 (See Table 9).

Table 9: Distribution of Toilets by School and Toilet Gap 


\begin{tabular}{|l|l|l|l|l|}
\hline School & Enrolment & $\begin{array}{l}\text { Number } \\
\text { of Toilets }\end{array}$ & $\begin{array}{l}\text { Toilets } \\
\text { Required }\end{array}$ & $\begin{array}{l}\text { Toilet } \\
\text { gap }\end{array}$ \\
\hline Bungano & 648 & 16 & 22 & 6 \\
\hline Chihame1 & 959 & 16 & 31 & 15 \\
\hline Chikumba & 423 & 8 & 14 & 6 \\
\hline Chimbere & 593 & 6 & 19 & 13 \\
\hline Msawa & 253 & 6 & 8 & 2 \\
\hline Chipayika & 490 & 6 & 16 & 10 \\
\hline Mgodi & 704 & 18 & 23 & 5 \\
\hline Msomba & 425 & 16 & 16 & 0 \\
\hline Uhoho & 504 & 12 & 16 & 4 \\
\hline Total & 4969 & 104 & 165 & 61 \\
\hline
\end{tabular}

Source: School Records.

According to head teacher of Chimbere lack of toilets contributed to absenteeism and dropout of pupils in his school and this is worse to aged girl pupils especially when they are menstruating. Dropoutb from school among girls for lack of sanitation is in agreement with UNICEF (2009) findings. In addition, pupils revealed that the problem is worse during break time as pupils wait on queue in order to use the toilet. As a result, many come to class late from break time, consequently disrupting ongoing lessons.

Table 10: Sselection to secondary school by the 9 schools

\begin{tabular}{|c|c|c|c|c|c|c|c|c|}
\hline School & Selected & Year & Girls & Boys & $\begin{array}{l}\text { Enrol } \\
\text { Girls }\end{array}$ & Boys & $\begin{array}{l}\% \text { Se } \\
\text { Girls }\end{array}$ & $\begin{array}{l}\text { n } \\
\text { oys }\end{array}$ \\
\hline Bungano & $\begin{array}{l}9 \\
5 \\
3 \\
4\end{array}$ & $\begin{array}{l}2009 \\
2010 \\
2011 \\
2012\end{array}$ & $\begin{array}{l}2 \\
1 \\
0 \\
1\end{array}$ & $\begin{array}{l}7 \\
4 \\
3 \\
3\end{array}$ & $\begin{array}{l}46 \\
42 \\
23 \\
17\end{array}$ & $\begin{array}{l}51 \\
62 \\
43 \\
46\end{array}$ & $\begin{array}{l}4.3 \\
2.3 \\
0 \\
5.8\end{array}$ & $\begin{array}{l}13.7 \\
6.4 \\
6.9 \\
6.5\end{array}$ \\
\hline Chihame & $\begin{array}{l}18 \\
6 \\
13 \\
10\end{array}$ & $\begin{array}{l}2009 \\
2010 \\
2011 \\
2012\end{array}$ & $\begin{array}{l}7 \\
1 \\
4 \\
1\end{array}$ & $\begin{array}{l}11 \\
5 \\
9 \\
10\end{array}$ & $\begin{array}{l}81 \\
38 \\
17 \\
46\end{array}$ & $\begin{array}{l}73 \\
56 \\
51 \\
63\end{array}$ & $\begin{array}{l}8.6 \\
2.6 \\
23.5 \\
2.1\end{array}$ & $\begin{array}{l}15 \\
8.9 \\
17.6 \\
15.8\end{array}$ \\
\hline
\end{tabular}




\begin{tabular}{|c|c|c|c|c|c|c|c|c|}
\hline Chikumba & $\begin{array}{l}3 \\
11 \\
12 \\
8\end{array}$ & $\begin{array}{l}2009 \\
2010 \\
2011 \\
2012\end{array}$ & $\begin{array}{l}1 \\
3 \\
3 \\
0\end{array}$ & $\begin{array}{l}2 \\
8 \\
9 \\
8\end{array}$ & $\begin{array}{l}15 \\
10 \\
9 \\
10\end{array}$ & $\begin{array}{l}25 \\
17 \\
14 \\
24\end{array}$ & $\begin{array}{l}6.6 \\
30 \\
33 \\
0\end{array}$ & $\begin{array}{l}8 \\
47 \\
64 \\
33\end{array}$ \\
\hline Chimbere & $\begin{array}{l}0 \\
0 \\
0 \\
1 \\
\end{array}$ & $\begin{array}{l}2009 \\
2010 \\
2011 \\
2012 \\
\end{array}$ & $\begin{array}{l}0 \\
0 \\
0 \\
0\end{array}$ & $\begin{array}{l}0 \\
0 \\
0 \\
1 \\
\end{array}$ & $\begin{array}{l}7 \\
13 \\
13 \\
10 \\
\end{array}$ & $\begin{array}{l}14 \\
18 \\
18 \\
16 \\
\end{array}$ & $\begin{array}{l}0 \\
0 \\
0 \\
10 \\
\end{array}$ & $\begin{array}{l}0 \\
0 \\
0 \\
6.2 \\
\end{array}$ \\
\hline Chintheche & $\begin{array}{l}0 \\
14 \\
14 \\
13\end{array}$ & $\begin{array}{l}2009 \\
2010 \\
2011 \\
2012\end{array}$ & $\begin{array}{l}0 \\
8 \\
6 \\
8\end{array}$ & $\begin{array}{l}0 \\
6 \\
8 \\
5\end{array}$ & $\begin{array}{l}4 \\
13 \\
68 \\
53\end{array}$ & $\begin{array}{l}17 \\
14 \\
67 \\
58\end{array}$ & $\begin{array}{l}0 \\
61.5 \\
8.8 \\
15\end{array}$ & $\begin{array}{l}0 \\
42.8 \\
11.9 \\
8.6\end{array}$ \\
\hline Chipayika & $\begin{array}{l}0 \\
0 \\
0 \\
0\end{array}$ & $\begin{array}{l}2009 \\
2010 \\
2011 \\
2012\end{array}$ & $\begin{array}{l}0 \\
0 \\
0 \\
0\end{array}$ & $\begin{array}{l}0 \\
0 \\
0 \\
0\end{array}$ & $\begin{array}{l}44 \\
50 \\
4 \\
3\end{array}$ & $\begin{array}{l}53 \\
65 \\
14 \\
18\end{array}$ & $\begin{array}{l}0 \\
0 \\
0 \\
0\end{array}$ & $\begin{array}{l}0 \\
0 \\
0 \\
0\end{array}$ \\
\hline Mgodi & $\begin{array}{l}28 \\
24 \\
25 \\
12 \\
\end{array}$ & $\begin{array}{l}2009 \\
2010 \\
2011 \\
2012 \\
\end{array}$ & $\begin{array}{l}9 \\
2 \\
2 \\
4 \\
\end{array}$ & $\begin{array}{l}19 \\
22 \\
23 \\
8 \\
\end{array}$ & $\begin{array}{l}36 \\
14 \\
17 \\
25 \\
\end{array}$ & $\begin{array}{l}58 \\
48 \\
44 \\
45 \\
\end{array}$ & $\begin{array}{l}25 \\
14.2 \\
11.7 \\
16 \\
\end{array}$ & $\begin{array}{l}32.7 \\
45.8 \\
52.2 \\
17.7 \\
\end{array}$ \\
\hline Msomba & $\begin{array}{l}7 \\
4 \\
10 \\
10 \\
\end{array}$ & $\begin{array}{l}2009 \\
2010 \\
2011 \\
2012 \\
\end{array}$ & $\begin{array}{l}2 \\
3 \\
6 \\
7 \\
\end{array}$ & $\begin{array}{l}5 \\
1 \\
4 \\
3 \\
\end{array}$ & $\begin{array}{l}33 \\
39 \\
39 \\
37 \\
\end{array}$ & $\begin{array}{l}20 \\
18 \\
29 \\
36 \\
\end{array}$ & $\begin{array}{l}6 \\
7.6 \\
15.3 \\
18.9 \\
\end{array}$ & $\begin{array}{l}25 \\
5.5 \\
13.7 \\
8.3 \\
\end{array}$ \\
\hline Uhoho & $\begin{array}{l}0 \\
0 \\
0 \\
3 \\
\end{array}$ & $\begin{array}{l}2009 \\
2010 \\
2011 \\
2012 \\
\end{array}$ & $\begin{array}{l}0 \\
0 \\
0 \\
0\end{array}$ & $\begin{array}{l}0 \\
0 \\
0 \\
1\end{array}$ & $\begin{array}{l}34 \\
37 \\
36 \\
32 \\
\end{array}$ & $\begin{array}{l}36 \\
32 \\
17 \\
14 \\
\end{array}$ & $\begin{array}{l}0 \\
0 \\
0 \\
0\end{array}$ & $\begin{array}{l}0 \\
0 \\
0 \\
7.1 \\
\end{array}$ \\
\hline Total & $\begin{array}{l}65 \\
64 \\
77 \\
60\end{array}$ & $\begin{array}{l}2009 \\
2010 \\
2011 \\
2012\end{array}$ & $\begin{array}{l}21 \\
18 \\
21 \\
21\end{array}$ & $\begin{array}{l}44 \\
46 \\
56 \\
39\end{array}$ & $\begin{array}{l}300 \\
256 \\
226 \\
233\end{array}$ & $\begin{array}{l}347 \\
330 \\
280 \\
320\end{array}$ & $\begin{array}{l}7 \\
7 \\
9.2 \\
9\end{array}$ & $\begin{array}{l}12 \\
13 \\
20 \\
12\end{array}$ \\
\hline Grand totals & $266(11.6 \%)$ & 4 (yrs) & 81 & 185 & 1015 & 1277 & $3.5 \%$ & $8.07 \%$ \\
\hline
\end{tabular}

Source: Nkhata Bay DEMISO and the District Education Manager

The study found that a total of 266 pupils (185 boys and 81 girls) had been selected to secondary schools from 2009 to 2012 in the nine schools under study (Table 10) out of a population of 2292 who sat the primary school leaving certificate examinations in those years, representing $11.6 \%$ or just $2.9 \%$ per year. A further analysis of the pass statistics shows that some schools did better than others. Schools closest to the Chintheche Trading Centre or with good accessroads, such as Mgodi, Chihame, Msomba, Bungano and Chikumba, performed much better throughout the 
years 2009-2012 while those far away from the trading centre and unreachable by regular transport, such as Chipayika, performed poorly. However, Uhoho, one of the grossly underperforming schools, close to the M5 road but with only two qualified teachers, one teacher's house (against 6 teachers), and lacking in learning resources, demonstrates that being accessible does not always guarantee getting the the learning materials and getting students into secondary school.

In general, the data reeal that combined the school performed poorly thoroughout the four years under examination. This underperformance at the zone level can be attributed to inadequate teachers, poor infrastructure and inadequate teaching and learning materials. As observed in preceding sections, in the zone under study, there was a desk gap of 1073.5; teacher gap of 411, a teachers' housing gap of 46, a classroom gap of 29 and a toilet gap of 61 not to mention textbook and notebook gaps. The least resourced school, Chipayika, saw no learner being selected to secondary for the fours studied. As observed earlier, Chipayika School had only two qualified teachers, inadequate infrastructure and no textbooks in some of the key subjects such as mathematics, science and agriculture.

Schools with better resources such as qualified teachers, teachers' houses, adequate classrooms, toilets performed better in terms of selection to secondary school. This is evident in schools such as Mgodi, Chihame and Chintheche. Since 2009 the selection of pupils from MSomba to secondary schools has been going upwards as reflected by 2011 and 2012 results which showed 10 pupils being selected against previous years 4 in 2010 and 7 in 2009. Msomba is the only school in the zone with electricity, affording pupils to study even at night. It also appears that the girls' performance at Msomba was higher in all the years than for boys except in 2009. It can be argued that the performance of Msomba School improved as resources increased. Apart from improved availability of infrastructure and teaching and learning materials, the girls' performance appeared to have improved because the school offers boarding facilities to all Standard eight (8) girl pupils and girls' security may have played a role.

\section{Conclusion and recommendations}

The study has demonstrated that quality education is an aspect of a combination of many factors. These include availability of teachers' houses, classroom, adequate supply of notebooks, adequate textbooks, the qualified teachers, and progressive national policies. Primary School Inprovment policy which allocated patry sums of money to school to purchase resources was a flop as it was not enough. The findings of this study supports the view that unequal distribution of resources affects the 
quality of education negatively resulting in the great education divide between 'urban' and rural schools, accessible and inacccesible schools, even rural education zones such as Chintheche. High teacher-pupil ratio and inadequate qualified teachers mean pupils cannot receive adequate attention from teachers and therefore they get compromised the education as teachers fail to satisfy pupils' needs. These short falls are reflected in the poor performance.

Similarly it has been demonstrated that most of the schools in Chintheche Education Zone lack adequate infrastructure such as teachers' houses; which makes allocation of teachers to some schools difficult. Lack of teachers' houses implies that teachers find accommodation away from the schools hence report for work late and tired, which makes it difficult for such teachers to deliver effectively. Teacher absenteeism is not uncommon. The study also found that most of the schools lack classroom blocks which negatively impacts the learning outcomes of the pupils.

It can be concluded that because the distribution of resources is not equal in Chintheche Education Zone primary schools, the learning outcome of pupils, that is, selection negatively. Schools with better supply and availability of resources are performing better in terms of selection of boys and girls to secondary school every year are able to send pupils to secondary school compared to schools with poor supplies and availability of resources. Education quality in schools in remote areas is poor and lower than in areas close to the Chintheche Township even though these schools follow the same syllabus and sit the same national examinations. These findings are in line with the findings of Darling-Hammond (2000) who found in the United States quality of teachers and teaching negatively or positively impact the outcomes of students in examinations even when background contexts are factored in. The study's findings also agree with those by Ndabi (1985) who concluded that in Tanzania lack of requisite resources affected quality primary school education delivery.

In terms of policy, the study recommends that in designing and implementing education policies governments should not rush until schools have enough resources in the form of teachers, teaching and learning materials, classrooms and washrooms; for quantity without quality is as bad as no education at all. As Yara and Otieno (2010) observed in a study on the teaching of mathematics in the Bondo district of Kenya, the resource challenge also affect student performance in secondary schools, thereby creating a cycle of underperforming students. Although the study only examined resources at the school itself, the input of parents in the achievement in school is equally important as Kaur \& Patiala (2013) found in the Punjab, India. A shared 
parent-government approach, experimented with in Tanzania (Chongo, 1994) would improve the quality of education delivery.

Academically, the study recommends that a fresh and more detailed study be conducted to examine how all these factors affect the quality of primary education in Malawi. A repeat study for the same zone would also be helpful in understanding if there are changes in resources distribution and how these affect pupil performance.

\section{References}

Alexander, F. (1999), History of Basic Education in Malawi. Blantyre: Dzuka.

Kaur, M \& Patiala, M (2013), A Study of Academic Achievement of School Students having illiterate and literate parents, Journal of Social Science Research, 1(1).

Chongo, P.N. (1994), The quality of Education in Tanzania Primary Schools: An assessment of Physical Facilities and Teaching Learning Materials, UTAFITI New Series, 1(1) retrieved from http://citeseerx.ist.psu.edu/viewdoc/download?doi=10.1.1.513.9993\&rep=rep1 \&type $=$ pdf

Darling-Hammond, L. (2000), Teachers' Quality and Students' Achievement. A Review of State Policy Evidence, Journal of Education Vol.8(1). Retrieved from https:/epaa.asu.edu/ojs/article/view/392/515

GoM (2007). Education Statistics 2007, Lilongwe: Ministry of Education, Science and Technology, Science and Technology.

GoM (2009), Education Sector Implementation Plan: Towards Quality Education: Implementing the National Education Sector Plan: 2009-2013. Lilongwe: Ministry of Education, Science and Technology. Retrieved from http://www.unesco.org/education/edurights/media/docs/bed24712c0c9703e8b 559eaaad0fe1dc90083112.pdf

GoM (2009), Malawi School Wash 2008: A Study Report on Water, Sanitation and Hygiene in Primary Schools. Lilongwe; Ministry of Education, Science and Technology \& Technology.

GoM (2009), Education Sector Implementation Plan. Lilongwe: Ministry of Education, Science and Technology, Science and Technology GoM (2012), Malawi Growth and Development Strategy 2011-2016. Lilongwe: Ministry of Economic Planning

Grogan, L. (2008), Universal Primary Education and School Entry in Uganda. Journal of African Economies, 18 (2). Retrieved from https://papers.ssrn.com/sol3/PIP_Journal.cfm?pip_jrnl=224847 
Hauya, R.T. and Makuwira, J. (1996), Basic Education in Malawi: Objectives problems and perspectives. Blantyre: Dzuka.

Kadzamira, E.C. and Chibwana, M. (2000), Gender and primary schooling in Malawi. IDS Research Report. Brighton: Institute of Development Studies.

Mathooko, P. (2010), Opportunities and Challenges for public primary school head teachers in the implementation of free primary education in Kisumu Municipality, Kenya: An Analytical assessment. Nairobi: Maseno University. Milner, G., Chimombo, J., Banda, T. and Mchikoma, C. (2001), The quality of primary education: Some policy suggestions based on a survey of schools, Malawi SECMEQ policy research Report. Paris: International Institute for education planning/ UNESCO. Retrieved from https://unesdoc.unesco.org/ark:/48223/pf0000123541/PDF/123541eng.pdf.multi

Ministry of Education, Science and Technology and Sports of Uganda (2005), Ministerial Seminar on Education for Rural People in Africa: Policy Lessons, Options and Priorities', Ministerial Seminar, Addis Ababa, Ethiopia, 7-9 September 2005.

Ministry of Education, Science and Technology Science and technology (2008), National Education Sector Plan 2008-2017. Lilongwe: MOEST.

Ndabi, D.M., (1985), The relationship between Selected Students Background School Characteristics and Academic Achievement in Standard seven Primary School Students in Tanzania, Ph.D. Dissertation Submitted to the University of Columbia. Retrieved from https://pk.tc.columbia.edu/item/B105842867758? fileId=11207

Ng'ambi, P. (2010), The Development of Education in Malawi 1996-2001. Zomba: University Of Malawi

Ngulube, J.A.K. (2010), Nkhata Bay District Social- Economic Profile (2010-2012). Nkhata Bay: Nkhata Bay District Council.

Nkhata Bay District Council (2009 a), Nkhata Bay District Socio-Economic Profile. Lilongwe: Ministry of Local Government \& Rural Development.

Nkhata Bay District Council (2009 b), Nkhata Bay District Development Plan 2009-2012. Lilongwe: Ministry of Local Government \& Rural Development.

Nkhata Bay District Council (2010), Nkhata Bay Education Plan FY2010/11-2012/13 Nkhata Bay. Lilongwe: Ministry of Local Governent and Rural Development

SACMEQ (2011). Quality of Primary school inputs in Malawi: Policy brief Number 2. Retrieved from http://www.sacmeq.org/sites/default/files/sacmeq/reports/sacmeq-iii/policybrief/mal_school_inputs_15oct2011_final.pdf 
UNESCO (2004), Education for All Global Monitoring Report. Paris: UNESCO

UNESCO (2009), Education for All (EFA) Global Status. Dakar: UNESCO.

UNESCO (2012), Education for All Global Monitoring Report-2012.Paris: UNESCO

Paris.

UNICEF (2009), Water, Sanitation and Hygiene Standards for Schools in Low-cost Settings. Retrieved from

https://www.who.int/water_sanitation_health/publications/wash_standards_s chool.pdf?ua $=1$

Yara, P. O. Otieno, K. O. (2010), Teaching/Learning Resources and Academic Performance in Mathematics Secondary Schools in Bondo District of Kenya. Asian Social Science (ASS), 6(12):126-132 Retrieved from http://www.ccsenet.org/journal/index.php/ass/article/download/8461/6304 